\title{
THE THERAPEUTIC EFFECT OF MORUS ALBA LEAF EXTRACT AND THE UNDERLYING MECHANISM ON A RABBIT MODEL OF DRY EYE
}

\author{
JINKUI CHENG, WENSHUI LU, XIAOMING CHEN, MENGNI WANG, TIAN TIAN * \\ Department of Ophthalmology, Jingzhou First People's Hospital (First Affiliated Hospital of Changjiang University), \\ Jingzhou, 434000, Hubei, China
}

*corresponding author: tiantianyanke1@163.com

Manuscript received: August 2020

\begin{abstract}
This study was aimed to evaluate the efficacy of different concentrations of mulberry leaf extract on the treatment of dry eye and the underlying mechanism using a model of a dry eye on castrated male rabbits. The Schirmer test (SIT) and tear break time (TBUT) were employed. After 14 days of treatment the animals were sacrificed and the lacrimal gland tissues was collected and used to determine the expressions of Bax, Bcl-2, Fas and FasL by Western blot and the expression of BAX protein by immunohistochemistry. The treatment with Morus alba leaf extract succeeded to significantly increase the score of SIT and TBUT test compared with the model group in a dose-dependent manner. This study showed that mulberry leaf extract could inhibit the expression of Bax, Fas and FasL in lacrimal gland cells of rabbits caused by androgen deficiency, thereby inhibiting lacrimal gland cell apoptosis and maintaining lacrimal gland basal secretion and could be a good candidate for replacing long term androgen therapy.
\end{abstract}

\section{Rezumat}

Acest studiu a avut ca scop evaluarea eficacităţii diferitelor concentrații de extract de frunze de dud în tratamentul ochiului uscat şi a mecanismului de bază ce stă la originea acestei afecțiuni, utilizând un model de xeroftalmie la iepuri masculi castrați. Au fost utilizate testul Schirmer (SIT) și timpul de lăcrimare (TBUT). După 14 zile de tratament, animalele au fost sacrificate și țesuturile de la nivelul glandei lacrimale au fost colectate și utilizate pentru a determina expresiile Bax, Bcl-2, Fas și FasL prin analiză Western blot și expresia proteinei Bax prin imunohistochimie. Tratamentul cu extract de frunze de Morus alba a influențat semnificativ scorul testului SIT și TBUT comparativ cu grupul model, într-o manieră dependentă de doză. Acest studiu a arătat că extractul de frunze de dud ar putea inhiba expresia Bax, Fas și FasL în celulele glandelor lacrimale ale iepurilor, cauzate de deficitul androgenic, inhibând astfel apoptoza celulară a glandei lacrimale, și menținând secreția bazală a glandei lacrimale, putând constitui un bun candidat pentru înlocuirea pe termen lung a terapiei cu androgeni.

Keywords: Morus alba leaf extract, dry eye, lacrimal gland, apoptosis, testosterone, rabbit model

\section{Introduction}

Dry eye, also known as keratoconjunctivitis, refers to any cause of abnormal tear quality or quantity, or dynamic abnormalities resulting in the decline of tear film stability, accompanied by eye discomfort and/or ocular surface pathological changes [1]. Dry eye is a common ocular surface disease, mostly binocular. Epidemiological and clinical studies have found that the incidence rate is far higher, the incidence of dry eye in Asians is about 17\% - 33\%, and the incidence in China is about $21 \%$ to $30 \%$, which means that one in three or four people may suffer from the dry eye syndrome [2]. The incidence in Europe and North America is less than in Asia, but on an increasing trend last year due to the increased time spent in front of computers and other screens of technologic devices [3, 4].

The latest definition of dry eye disease given by the International Dry Eye Research Association is: multifactor diseases of tear and eyeball surface that can cause discomfort, visual disturbance, tear film instability and damage eyeball surface [5]. Oxidative stress appears to be involved in most ocular disorders, including macular degeneration, myopia, glaucoma, and dry eye pathology [6]. The last one is associated with increased tear film permeability and ocular surface inflammation [7]. Although the initial causes of dry eye disease are different, once entering the progressive stage, inflammation becomes the most critical factor in the pathogenesis of dry eye disease, and apoptosis, regulation of the nutrients and sex hormones also participate in the pathogenesis of dry eye disease [8]. In a dry eye, the apoptosis of lacrimal gland and ocular surface epithelial cells increase abnormally, while the apoptosis of lymphocytes in local tissues is inhibited. On the one hand, it lids to the damage and destruction of ocular tissues and the prolongation of the survival time of lymphocytes that promote the activation of inflammation [9]. The increased expression of pro-apoptotic factors (FAS (or apoptosis antigen 1), FasL (Fas Ligand)) and inflammatory factors (such as interleukine-1 (IL-1)) in the ocular surface 
and tears of patients with dry eye can activate the apoptotic pathway, while the apoptotic rate depends on the balance between Bcl-2 (B-cell lymphoma 2), Bax (bcl-2-like protein 4) and the interaction between Fas and FasL [10].

The eye is one of the target organ of sex hormones. It has been proved that androgen, progesterone, oestrogen and prolactin receptors widely exist in the tear gland, meibomian gland, cornea and other ocular surface tissues of human, rabbit and mouse. Sex hormones, especially androgens, can regulate the immune function of the body and local, and regulate the morphology, development, differentiation and secretion function of the lacrimal gland and meibomian gland. The causes of androgen deficiency, such as menopause, ageing, autoimmune diseases and antiandrogen drugs, can cause the dry eye syndrome [11-14].

Mulberry leaves, Morus alba L. (Moraceae family) have a series of active components from the flavonoids class, which can efficiently treat dry eyes caused by the decrease of androgen levels [15-17].

In this study, we aimed to evaluate the effects of different concentrations of mulberry leaf extract in the treatment of dry eye and the underlying mechanism using a model of dry eye on castrated male rabbits.

\section{Materials and Methods}

\section{Animals}

Forty-two healthy adult male New Zealand white rabbits aged 10 weeks with a bodyweight of 1.5 $2.0 \mathrm{~kg}$ were selected. The animals were randomly divided into 7 groups, with 6 animals per group as follows: group A: blank group, group B: model group, group $\mathrm{C}$ : low mulberry leaf extract concentration group, group D: medium mulberry leaf extract concentration group, group E: high mulberry leaf extract concentration group, group F: placebo group, group G: testosterone group. This study was approved by the Animal Care Use Committee of Jingzhou First People's Hospital and followed the ARRIVE guidelines for reporting experiments using live animals and the international directives of animal protection.

Dry eye murine model: The rabbit from groups B-G underwent bilateral testis and epididymis resection to obtain the androgen-deficiency dry eye model based on previous studies [18]. Before the experiment, we purchased 42 healthy adult New Zealand white rabbits aged 10 weeks with the weight of $1.5 \sim 2.0 \mathrm{~kg}$ (Shanghai Jiagan Biotechnology Company, China), and the animals were kept in the normal environment for at least one week for acclimatization (relative humidity: $60 \sim 70 \%$; air flow rate: $0.2 \mathrm{~m} / \mathrm{s}$; temperature: $23-25^{\circ} \mathrm{C}$ ).

Treatment

The animals in the blank group (group A) received no intervention or treatment. The animals from group
$\mathrm{B}$ represented the control group and received no treatment after modelling. The animals from group $\mathrm{C}$, group D and group E received mulberry leaf extract eye drops $2.5,5$ and $10 \mu \mathrm{g} / \mathrm{mL}$, respectively for 14 days. Preparation method of mulberry leaf extract eye drops: Dry mulberry leaves (Beijing TongRenTang Co., Ltd., China) $10 \mathrm{~kg}$ were washed and crushed. Then the dried leaves were extracted twice with $60 \%$ ethanol (Tianjin Jingming New Technology Development Co. Ltd, China) in proportion of 10x leaf quantity for the first time, and 8x leaf quantity the second time. The ethanolic extracts were combined and then the ethanol was recovered under reduced pressure. The concentrated solution is treated with $0.2 \%$ ZTC clarifier (Tianjin Jingming New Technology Development Co. Ltd, China), filtered and then the filtrate is passed through HPD-100 macroporous resin column (Tianjin Jingming New Technology Development Co. Ltd, China) for gradient elution with different concentrations of ethanol. Then the $60 \%$ ethanol eluent was collected and the remaining was dried in vacuum and crushed into a dry paste till the final product of $0.2 \mathrm{~kg}$ dry paste. The yield of total flavonoids and total phenylpropanol extract from mulberry leaves was $2 \%$. The dried paste was diluted with bi-distilled water and used to prepare the $2.5,5$ and $10 \mu \mathrm{g} / \mathrm{mL}$ mulberry leaf extract eye drops in $0.1 \%$ solution of hydroxypropyl methylcellulose (Tianjin Jingming New Technology Development Co. Ltd, China). Tear film rupture time, tear secretion and corneal epithelial damage were observed after the last administration. The animals in group F received saline solution (Sigma, USA) for 14 days. The animals in group $\mathrm{G}$, received an intramuscular injection of testosterone propionate (Sigma, USA) at a dose of $0.5 \mathrm{~mL} / \mathrm{kg}$ bw, once every three days for 14 days.

Measurements

Schirmer test (SIT) and tear break-up time (TBUT) were measured before and 14 days after the operation. Schirmer test was performed using special paper bands (GE Whatman, 8114-2250, UK). After anaesthesia with sevoflurane (Tianjin Jingming New Technology Development Co. Ltd, China), the New Zealand white rabbits were fixed in a supine position on a fixed frame. After fixing the limbs, according to the SIT test instructions, the tear secretion test paper was placed in the junction of the middle and outer $1 / 3$ of the conjunctival sac under the tested eye. Then the rabbit eyes were closed and the filter paper was collected after 5 minutes. On the paper, the investigator measured the wet length of the filter paper strip with a micrometer.

For the tear break-up time (TBUT) measurement, the following protocol was used: the New Zealand white rabbits were anesthetized with sevoflurane (Tianjin Jingming New Technology Development Co. Ltd, China) and then fixed on a fixed frame in a supine position. After the limbs were fixed, the fluorescein 
FARMACIA, 2021, Vol. 69, 2

sodium ophthalmic test paper (Tianjin Jingming New Technology Development Co. Ltd, China) was partially moistened with saline, and the lower eyelid fornix was gently wiped, and the upper and lower eyelids were gently rubbed to perform its dispersion. Then the tear film rupture time was observed for 3 consecutive times and the media was recorded.

After 14 days, the rabbits in each group were killed by air embolism, and the lacrimal gland tissues of both eyes were removed.

Western blot

The expressions of Bax, Bcl-2, Fas and FasL in lacrimal gland cells were detected by Western blot. The tissue pieces were washed 2 - 3 times with cold phosphate buffered saline (PBS) (Sigma, USA) to remove blood stains and then cut into small pieces and homogenized. Then the tissue homogenate was mixed in proportion of 1:10 with protease inhibitor and/or phosphatase inhibitor and homogenized thoroughly on ice till complete cell lysis. Then the samples were centrifuged at $12,000 \mathrm{~g}$ for $10 \mathrm{~min}$, and the supernatant was collected. The protein electrophoresis was performed by mixing $30 \mu \mathrm{g}$ sample with $4-20 \%$ of the precast gel into the electrophoresis buffer on each well, each sample being assessed in triplicate at 120 V. After electrophoresis completion, the membrane transfer on realized on PVDF membrane (Sigma, USA) at $380 \mathrm{~mA}$ for 100 minutes. After membrane transfer, $5 \%$ skimmed milk powder was added and let to react for 45 minutes and then the membranes were washed with water and incubated at $4^{\circ} \mathrm{C}$ with the primary antibodies: anti-Bax (1:1000) (MA5-35342, Thermo, USA), anti-Bcl-2 (1:1000) (MHBCL01, Thermo, USA), anti-Fas (1:1000) (BMS140FI, Thermo, USA) and anti-FasL (1:1000) (PA5-84227, Thermo, USA). After incubation, the PVDF membrane was washed twice with PBS for 15 min each time. Then the membranes were incubated for $1 \mathrm{~h}$ at room temperature with the HRP Goat Anti-Rabbit IgG $(\mathrm{H}+\mathrm{L})$ secondary antibody (1:10000) (Thermo, USA). After incubation with the secondary antibody, the membrane was washed twice with PBS for 15 minutes each time before visualization using a chemiluminescent (ECL) substrate. As ECL substrate it was used a mixture of ECL solution A and $\mathrm{B}$ (Thermo, USA) at a ratio of $1: 1$ to cover the membrane and was incubated at room temperature in dark for 20 minutes. The membranes were scanned and the optical density was evaluated using Image-J analysis software.

Immunohistochemistry

The expression of Bax protein apoptotic factor was evaluated by immunohistochemistry. Briefly, the tissue was washed with saline solution and fixed in $4 \%$ neutral formaldehyde (BL600A, Biosharp, China) and the standard paraffin-embedded blocks were obtained. The 2 - $4 \mu$ m-thick paraffin-embedded samples were deparaffinized for 10 minutes in xylene I and xylene II (Sigma, USA) and then passed for 2 - 5 minutes in decreasing concentrations of alcohol as follows: $100 \%, 95 \%, 80 \%, 70 \%$ alcohol (Sigma, USA) for 2 - 5 minutes and then washed with tap water for 2 minutes. After washing, the samples were incubated with $3 \% \mathrm{H}_{2} \mathrm{O}_{2}$ (Sigma, USA) at room temperature for $10 \mathrm{~min}$ to block endogenous peroxidase and washed with PBS (Sigma, USA) for 2 min for 3 consecutive times. Then the primary antibody: Bax anti-rabbit monoclonal antibody (dilution 1:200) (14-6999-82, Thermo, USA) was added to each slice and incubated for $1-2 \mathrm{~h}$ at $37^{\circ} \mathrm{C}$. After incubation, the samples were rinsed with PBS for 2 min for 3 consecutive times and incubated at $37^{\circ} \mathrm{C}$ for 30 minutes with Polymer Helper (PV-9000, GBI, USA) added in drops. After incubation, the samples were rinsed with PBS for 2 minutes for 3 consecutive times and the second antibody, polyperoxidase-anti-rabbit IgG (PV-9000, GBI, USA) was added in drops and incubated at $37^{\circ} \mathrm{C}$ for 20 - 30 min. After incubation the samples were rinsed with PBS for 2 min for 3 consecutive times and the colour was developed using DAB (Sigma, USA) solution. Bax protein expression was observed under a high-power microscope.

After immunohistochemical reaction, the cytoplasm of positively labelled cells was brown or dark brown. The images were analysed using Image-J analysis software.

\section{Statistical analysis}

All experimental data were processed by SPSS 16.0 statistical software (IBM, USA). The measurement data is expressed as mean \pm standard deviation. If the normality and homogeneity of variance are satisfied, the analysis of variance is used. If the normality and the homogeneity of variance are not satisfied, nonparametric multiple comparisons were used. $\chi^{2}$ test was used for counting data, and the rank-sum test was used for those with uneven variance. A value of $\mathrm{p}<$ 0.05 was considered statistically significant.

\section{Results and Discussion}

SIT and BUT value

Before modelling there were no differences between the groups for SIT and TBUT scores. After modelling, it is observed a significant decrease in the SIT and TBUT scores in the model group (group B) compared with the blank group and the same trend was observed also in the placebo group (Group F). The treatment with testosterone (group G) significantly increased the SIT and TBUT levels compared with the model group (group B). The treatment with mulberry leaf extract succeeded to significantly increase the scores of SIT and TBUT tests compared with the model group in a dose-dependent manner $(\mathrm{p}<0.01)$. The effect was similar with testosterone for all 3 doses for SIT score and only for the medium (group D) and high doses (Group E) for TBUT score $(p<0.01)$ (Table I). 
SIT and TBUT value of rabbits in each group before and after the operation $(n=6)$

\begin{tabular}{|c|c|c|c|c|c|c|c|}
\hline & Group A & Group B & Group C & Group D & Group E & Group F & Group G \\
\hline \multicolumn{8}{|c|}{ SIT } \\
\hline Preoperation & $14.71 \pm 2.13$ & $14.88 \pm 2.09$ & $14.98 \pm 1.46$ & $14.78 \pm 1.46$ & $14.55 \pm 1.35$ & $14.66 \pm 1.95$ & $14.67 \pm 1.79$ \\
\hline Postoperation & $14.52 \pm 1.32$ & $7.46 \pm 1.68^{\# \#}$ & $14.13 \pm 1.14 * *$ & $14.14 \pm 1.13 * *$ & $14.18 \pm 1.35^{* *}$ & $7.32 \pm 1.45^{\# \#}$ & $14.35 \pm 1.49 * *$ \\
\hline \multicolumn{8}{|c|}{ TBUT } \\
\hline Preoperation & $14.35 \pm 2.57$ & $14.47 \pm 1.35$ & $14.45 \pm 1.49$ & $14.59 \pm 1.12$ & $14.69 \pm 1.56$ & $14.29 \pm 2.31$ & $14.73 \pm 2.14$ \\
\hline Postoperation & $14.04 \pm 1.45$ & $6.79 \pm 1.56^{\# \#}$ & $12.86 \pm 1.51^{*}$ & $14.03 \pm 1.21 * *$ & $14.03 \pm 1.28 * *$ & $* 6.32 \pm 1.57^{\# \#}$ & $14.58 \pm 1.33 * *$ \\
\hline
\end{tabular}

Expression of Bax, Bcl-2, Fas and FasL in lacrimal gland cells of rabbits in each group after operation The Bax, Fas and FasL expression significantly increased in the model group (group B) and placebo group (group $\mathrm{F}$ ) after modelling $(\mathrm{p}<0.01)$ while Bcl-2 expression significantly decreased in the model group (group B) and placebo group (group F) after modelling $(\mathrm{p}<0.01)$. The treatment with testosterone (group G) significantly decreased the Bax, Fas and FasL expression levels and significantly increased Bcl-2 expression levels compared with the model group (group B) $(\mathrm{p}<0.01)$. The treatment with mulberry leaf extract succeeded to significantly decrease the Bax, Fas and FasL expression levels and to significantly increase Bcl-2 expression levels compared with the model group in a dose-dependent manner. The medium and high dose of mulberry leaf extract succeeded to reverse the increase of Bax, Fas and FasL expression till the levels obtained after the administration of testosterone (group G), while for the Bcl-2 expression all the 3 doses were efficient in significantly increasing the levels above the control group and above the levels of testosterone treated group (group G) (Figure 1 and Table II).

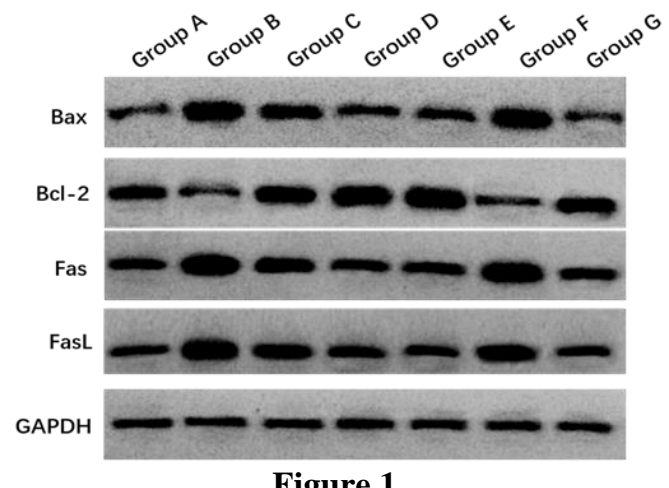

Expression of Bax, Bcl-2, Fas and FasL protein in A-G groups by Western Blot

Table II

Mean optical density of Bax, Bcl-2, Fas and FasL in lacrimal gland cells of rabbits in each group

\begin{tabular}{lcccc}
\hline & Bax & Bcl-2 & Fas & FasL \\
\hline Group A & $0.13 \pm 0.23$ & $0.36 \pm 0.16$ & $0.25 \pm 0.03$ & $0.25 \pm 0.09$ \\
Group B & $0.54 \pm 0.32^{* *, \& \&}$ & $0.17 \pm 0.64^{* *, \& \&}$ & $0.66 \pm 0.09^{* *, \& \&}$ & $0.53 \pm 0.23^{* *, \& \&}$ \\
Group C & $0.37 \pm 0.13^{*, \#, \&}$ & $0.52 \pm 0.15^{*, \#, \&}$ & $0.47 \pm 0.21^{*, \#, \&}$ & $0.35 \pm 0.13^{*, \&}$ \\
Group D & $0.25 \pm 0.15^{* *, \# \#}$ & $0.66 \pm 0.16^{* *, \# \#, \& \&}$ & $0.33 \pm 0.15^{\# \#}$ & $0.23 \pm 0.07^{\# \#}$ \\
Group E & $0.23 \pm 0.16^{* *, \# \#}$ & $0.69 \pm 0.13^{* *, \#, \& \&}$ & $0.35 \pm 0.15^{\# \#}$ & $0.24 \pm 0.15^{\# \#}$ \\
Group F & $0.54 \pm 0.22^{* *, \& \&}$ & $0.14 \pm 0.43^{* *, \& \&}$ & $0.67 \pm 0.14^{* *, \& \&}$ & $0.53 \pm 0.42^{*,, \& \&}$ \\
Group G & $0.15 \pm 0.26^{\# \#}$ & $0.37 \pm 0.15^{\# \#}$ & $0.34 \pm 0.15^{\# \#}$ & $0.23 \pm 0.06^{\# \#}$ \\
\hline
\end{tabular}

${ }^{*} \mathrm{p}<0.05$ compared with group $\mathrm{A} ;{ }^{* *} \mathrm{p}<0.01$ compared with group $\mathrm{A} ;{ }^{\#} \mathrm{p}<0.05$ compared with group $\mathrm{B}, \mathrm{p}<0.05,{ }^{\# \#} \mathrm{p}<0.01$ compared with group $\mathrm{B} ;{ }^{\&} \mathrm{p}<0.05$ compared with group $\mathrm{G} ;{ }^{\& \&} \mathrm{p}<0.01$ compared with group $\mathrm{G}$

Light microscopic observation on the expression of Bax in each group after operation

In the blank control group (group A), the lacrimal gland tissue was arranged orderly, the cell structure was clear, no inflammatory cell infiltration, no apoptosis cell, no Bax expression ( $\times 400$ times) were determined. In the model group (group B), the lacrimal gland was irregularly arranged, the cell structure presented large degenerations, there were observed inflammatory cell infiltration and apoptosis, Bax was expressed in the cell membrane and cytoplasm, and there were brownish yellow granules $(\times 400)$. In group $C$, the lacrimal gland tissue was arranged orderly, the cell structure was clear, there was a small amount of inflammatory cell infiltration and apoptosis, Bax was expressed in the cell membrane and cytoplasm, and there were brownish yellow granules (x 400). In group $\mathrm{D}$, the lacrimal gland tissue was arranged orderly, the cell structure was clear, a small number of inflammatory cells infiltrated and apoptosis, Bax was expressed in the cell membrane and cytoplasm, and there were brownish yellow granules (x 400).

In the high concentration mulberry leaf extract group (Group E), the lacrimal gland tissue was arranged orderly, the cell structure was clear, there were a small amount of inflammatory cell infiltration and 
apoptosis, and Bax was scattered in the cell membrane and cytoplasm, presenting brownish yellow granules (x 400). In the placebo eye drop group (Group F), the lacrimal gland tissue was irregularly arranged, the cell structure was large-scaled degenerated, there was massive inflammatory cell infiltration and apoptosis, Bax was expressed in the cell membrane and cytoplasm, and there were brownish yellow particles $(\times 400)$. In the testosterone group (G group), the lacrimal gland tissue was arranged orderly, the cell structure was clear, inflammatory cell infiltration and apoptosis were scattered, Bax was expressed in cell membranes and cytoplasm, and also brown granules ( $\mathrm{x}$ 400) (Figure 2).

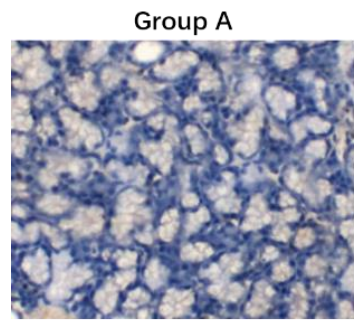

Group E

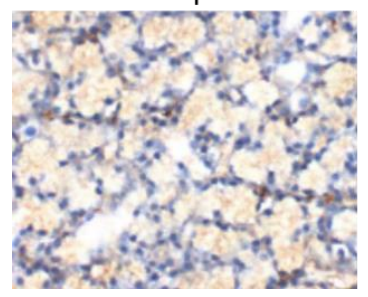

Light microscopic observation on the expresion of

Figure 2.
Group C

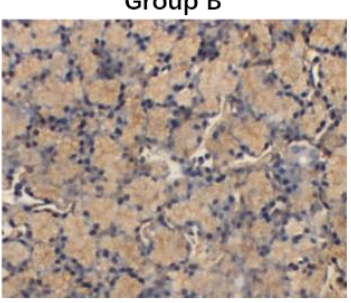

Group F

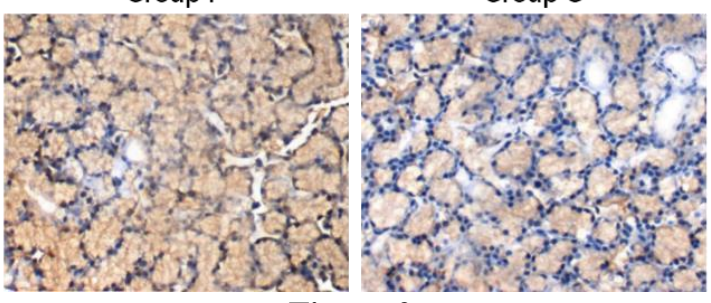

Group G

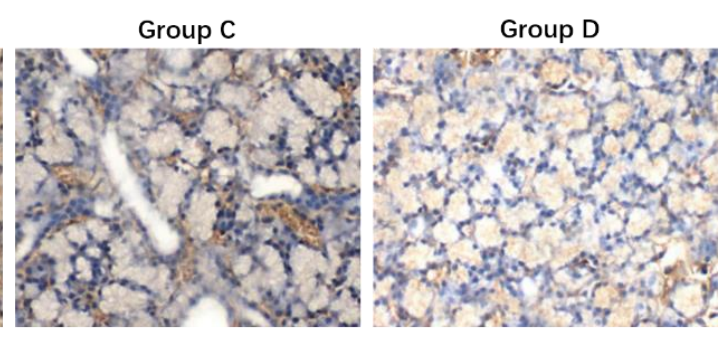

the

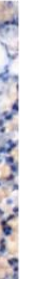

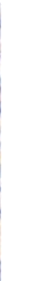

xpression of Bax in A-G groups after the operation

Multifactorial diseases of tear and eyeball surface can cause eye discomfort, visual impairment, tear film instability and damage eyeball surface. The disease is accompanied by increased tear film permeability and ocular surface inflammation. Although the initial causes of keratoconjunctivitis are different, once it enters the progressive stage, inflammation becomes the most critical factor in the pathogenesis of dry eye, and apoptosis, neuromodulation and sex hormones also participate in its pathogenesis $[5,6]$. The expression of pro-apoptotic factors (Bax, Fas, FasL) and proinflammatory factors (IL-1, TNF - $\alpha$ ) in the ocular surface and tear of patients with dry eye can activate the apoptotic pathway [7].

At present, the treatment of keratoconjunctivitis is mainly based on drugs [19], and the commonly used drugs in clinic are artificial tears. This kind of drugs mainly relieve the discomfort of patients' eyes, but cannot fundamentally change the pathological state of the dry eye.

Mulberry leaves contain flavonoids with hormonelike properties with a similar effect in inhibiting apoptosis as androgens [20, 21]. In comparison with androgens, mulberry leaf extract has fewer side effects, but a similar therapeutic effect in this regard, being good candidates for systemic androgen substitution [22] that are worth investigated in future human studies. In the current study, we observed that mulberry leaf extract could inhibit the expression of androgen-like apoptosis factors in the dry eye androgen deficiency model by downregulating the expression of Bax, Fas and FasL and upregulating the expression of Bcl-2 in a dose-dependent manner. There was no significant difference between these doses. A previous study showed that mulberry leaf extract can increase testosterone production in diabetic rats through modulation of StAR mRNA expression [23], and this could be another mechanism implicated in the decrease of testosteroneinduced apoptosis observed in our study.

\section{Conclusions}

This study showed that mulberry leaf extract could inhibit the expression of Bax, Fas and FasL in lacrimal gland cells of rabbits caused by androgen deficiency, thereby inhibiting lacrimal gland cell apoptosis and maintaining lacrimal gland basal secretion, but its effect was weaker compared with the androgen hormones. This study not only provides a new natural drug for the treatment of dry eye but also can be a good alternative for preventing the adverse reactions caused by long-term use of androgens. Further human studies should be performed in order to confirm the animal data.

\section{Conflict of interest}

The authors declare no conflict of interest.

\section{References}

1. Schaumberg DA, Buring JE, Sullivan DA, Hormone replacement therapy and dry eye syndrome. JAMA, 2001; 286(17): 2114-2119. 
2. Miljanović B, Dana R, Sullivan DA, Schaumberg DA, Impact of dry eye syndrome on vision-related quality of life. Am J Ophthalmol., 2007; 143(3): 409-415.

3. Schaumberg DA, Dana R, Buring JE, Sullivan DA, Prevalence of dry eye disease among US men: estimates from the Physicians' Health Studies. Arch Ophthalmol., 2009; 127(6): 763-768.

4. Nakamura S, Approach to Dry Eye in Video Display Terminal Workers (Basic Science). Invest Ophthalmol Vis Sci., 2018; 59(14): DES130-DES137.

5. Lemp MA, The Definition and Classification of Dry Eye Disease: Report of the Definition and Classification Subcommittee of the International Dry Eye Workshop (2007). Ocul Surf., 2007; 5(2): 75-92.

6. Coviltir V, Burcel M, Cherecheanu AP, Ionescu C, Dascalescu D, Potop V, Burcea M, Update on myopia risk factors and microenvironmental changes. J Ophthalmol., 2019; 2019: 4960852: 1-9.

7. Sullivan DA. Tearful Relationships? Sex, Hormones, the Lacrimal Gland, and Aqueous-Deficient Dry Eye. Ocular Surface., 2004; 2(2): 92-123.

8. Cruz AAV, Equiterio BSN, Cunha BSA, Caetano FB, Souza RL, Deep lateral orbital decompression for Graves orbitopathy: A systematic review. Int Ophthalmol., 2021. doi: 10.1007/s10792-021-01722-3.

9. Spinozzi E, Baldassarri C, Acquaticci L, Del Bello F, Grifantini M, Cappellacci L, Riccardo P, Adenosine receptors as promising targets for the management of ocular diseases. Med Chem Res., 2021: 1-18.

10. Favero G, Moretti E, Krajčíková K, Tomečková V, Rezzani R, Evidence of Polyphenols Efficacy against Dry Eye Disease. Antioxidants, 2021; 10(2): 190: 1-17.

11. Clayton JA, Dry Eye. N Engl J Med., 2018; 378(23): 2212-2223.

12. Messmer EM, The pathophysiology, diagnosis, and treatment of dry eye disease. Dtsch Arztebl Int., 2015; 112(5): 71-81.

13. Rouen PA, White ML, Dry Eye Disease: Prevalence, Assessment, and Management. Home Healthc Now., 2018; 36(2): 74-83.

14. Toda I, Dry Eye After LASIK. Invest Ophthalmol Vis Sci., 2018; 59(14): 109-115.

15. Ouyang Z, Chen J, Research Progress on Chemical Constituents and Pharmacological Activities of
Mulberry Leaves. J Jiangsu Univ.. 2003; 24(6): 3944, (available in Chinese).

16. Assiri AMA, El-Beeh ME, Amin AH. Ameliorative impact of Morus alba leaves' aqueous extract against embryonic ophthalmic tissue malformation in streptozotocin-induced diabetic rats. Biomed Pharmacother., 2017; 95: 1072-1081.

17. Liu Y, Li Y, Peng Y, Dietary mulberry leaf powder affects growth performance, carcass traits and meat quality in finishing pigs. J Anim Physiol Anim Nutr (Berl), 2019; 103(6): 1934-1945.

18. Sullivan DA, Sullivan BD, Evans JE, Schirra F, Yamagami H, Liu M, Richards SM, Suzuki T, Schaumberg DA, Sullivan RM, Dana MR, Androgen deficiency, Meibomian gland dysfunction, and evaporative dry eye. Ann N Y Acad Sci., 2002; 966: 211-222.

19. Irimia T, Muşat GC, Prisada RM, Ghica MV, DinuPîrvu CE, Anuţa V, Velescu BS, Popa L, Contributions on formulation and preliminary evaluation of ocular colloidal systems of chitosan and poloxamer 407 with bupivacaine hydrochloride. Farmacia, 2019; 67(4): 702-708.

20. Liang HW, Yang TY, Teng CS, Lee YJ, Yu MH, Lee HJ, Hsu LS, Wang CJ, Mulberry leaves extract ameliorates alcohol-induced liver damages through reduction of acetaldehyde toxicity and inhibition of apoptosis caused by oxidative stress signals. Int $J$ Med Sci., 2021; 18(1): 53-64.

21. Naowaratwattana W, De-Eknamkul W, De Mejia EG, Phenolic-containing organic extracts of mulberry (Morus alba L.) leaves inhibit HepG2 hepatoma cells through G2/M phase arrest, induction of apoptosis, and inhibition of topoisomerase II $\alpha$ activity. $J$ Med Food, 2010; 13(5): 1045-1056.

22. Zhang Y, Ren C, Lu G, Mu Z, Cui W, Gao H, Wang $\mathrm{Y}$, Anti-diabetic effect of mulberry leaf polysaccharide by inhibiting pancreatic islet cell apoptosis and ameliorating insulin secretory capacity in diabetic rats. Int Immunopharmacol., 2014; 22(1): 248-257

23. Hajizadeh MR, Eftekhar E, Zal F, Jafarian A, Mostafavi-Pour Z, Mulberry leaf extract attenuates oxidative stress-mediated testosterone depletion in streptozotocin-induced diabetic rats. Iran J Med Sci., 2014; 39(2): 123-129. 